\title{
Kualitas Minyak Ikan Lele Dumbo (Clarias gariepinus) Selama Penyimpanan dengan Penambahan Likopen Kasar dari Buah Tomat
}

\section{[Quality of Dumbo Catfish Oil (Clarias gariepinus) During Storage with The Additing of Crude Lycopene from Tomatoes]}

\author{
Heince Andre Pua*, Nurhaeni, Erwin Abdul Rahim, Prismawiryanti \\ Jurusan Kimia Fakultas MIPA Universitas Tadulako, Jalan Soekarno-Hatta Km. 9, Palu, Indonesia
}

\begin{abstract}
The quality of Dumbo Catfish (Clarias gariepinus) oil can be maintained during storage with the addition of crude lycopene in tomatoes as an antioxidant. The purpose of this study was to obtain the best ratio between crude lycopene in tomatoes and Dumbo catfish oil during storage. The study was conducted using a variable ratio of crude lycopene: Dumbo catfish oil with 4 treatment levels $(6: 40,8: 40,10: 40$, and 12:40 $(\mathrm{w} / \mathrm{v}))$ and storage time variables of 1, 2, 3, and 4 weeks. Lycopene levels in Dumbo catfish oil were analyzed using a UV-Vis spectrophotometer, while the quality of Dumbo catfish oil during storage was determined through peroxide value analysis. The results showed that the best ratio of crude lycopene of tomatoes: Dumbo catfish oil was 12:40 at the third week of storage with lycopene content of 0.257 grams and the peroxide value of Dumbo catfish oil was 3.45 $\mathrm{meq} / \mathrm{kg}$ or had met IFOS standards.
\end{abstract}

Keywords: Crude lycopene, tomato fruit, dumbo catfish oil, peroxide value.

Abstrak. Kualitas minyak ikan lele dumbo (Clarias gariepinus) mampu dipertahankan selama penyimpanan dengan penambahan likopen kasar buah tomat sebagai antioksidan. Tujuan dari penelitian ini adalah untuk mendapatkan rasio terbaik antara likopen kasar buah tomat terdahap minyak ikan lele dumbo selama penyimpanan. Penelitian dilakukan dengan menggunakan variabel rasio likopen kasar terhadap minyak ikan lele dumbo sebanyak 4 taraf perlakuan $(6: 40,8: 40,10: 40$, dan 12:40 (b/v)) dan variabel waktu penyimpanan 1, 2, 3, dan 4 minggu. Kadar likopen dalam minyak ikan lele dumbo dianalisis menggunakan spektrofotometer UV-Vis, sedangkan kualitas minyak ikan lele dumbo selama masa penyimpanan ditentukan melalui analisis bilangan peroksida. Hasil penelitian menunjukan bahwa rasio terbaik likopen kasar buah tomat terhadap minyak ikan lele adalah 12:40 pada penyimpanan minggu ketiga dengan kadar likopen 0,257 gram dan bilangan peroksida minyak ikan lele dumbo $3,45 \mathrm{meq} / \mathrm{kg}$ atau telah memenuhi standar IFOS.

Kata kunci: Likopen kasar, buah tomat, minyak ikan lele dumbo, bilangan peroksida.

Diterima: 9 Oktober 2019, Disetujui: 23 Agustus 2021

Sitasi: Pua, H A., Nurhaeni., Rahim, E A., dan Prismawiryanti. (2021). Kualitas Minyak Ikan Lele Dumbo (Clarias gariepinus) Selama Penyimpanan dengan Penambahan Likopen Kasar dari Buah Tomat. KOVALEN: Jurnal Riset Kimia, 7(2): 154-160.

\section{LATAR BELAKANG}

Ikan lele dumbo merupakan jenis hibrida lele dari Taiwan yang masuk ke Indonesia dan dikenal dengan nama ilmiah Clarias gariepinus

\footnotetext{
* Corresponding author

E-mail: heinceandrepua15@gmail.com
}

atau lebih populer dengan nama king catfish yang berarti raja ikan lele. Pertumbuhan lele dumbo sangat cepat atau dapat mencapai ukuran besar dengan jangka waktu pemeliharaan yang singkat, sehingga diberi nama lele dumbo (Suyanto, 2006). Produksi 
ikan lele di Indonesia dapat mencapai 10 persen dari total perikanan budidaya nasional dengan rata-rata tingkat pertumbuhan 39,66 persen per tahun (Ngadiarti et al., 2013). Salah satu produk pengolahan ikan lele yang bermutu dan bermanfaat bagi kesehatan manusia yaitu minyak ikan lele.

Minyak dari ikan lele dumbo memiliki kandungan asam lemak tidak jenuh yang cukup tinggi, yang terdiri dari asam lemak tak jenuh tunggal $33 \%$ dan tak jenuh ganda $32 \%$ (Ngadiarti et al., 2013) . Ikan ini tergolong ikan air tawar dengan kandungan asam lemak tak jenuh omega-3 (asam linoleat, asam eikosapentaenoat, dan asam dokosahek saetanoat, yang memiliki fungsi dapat membantu mencegah penyakit degeneratif dan jantung koroner (Erdman et al., 2012). Minyak ikan lele dengan kandungan asam lemak tak jenuh yang melimpah akan dengan mudah mengalami kerusakan akibat reaksi oksidasi.

Oksidasi pada minyak terjadi saat asam lemak tidak jenuh bereaksi dengan oksigen pada ikatan rangkapnya, sehingga terbentuk hidroperoksida atau peroksida yang bersifat karsinogenik atau dapat menyebabkan penyakit kanker. Hal ini diakibatkan berbagai faktor, seperti cahaya, suhu tinggi dan lain-lain (Burhan, 2018). Untuk menanggulangi masalah tersebut perlu adanya penambahan suatu senyawa antioksidan yang dapat menghambat atau mengoptimalisasikan kerusakan pada minyak ikan lele. Sumber antioksidan yang potensial dapat bersumber dari buah-buahan yang berwarna merah, salah satunya sumber antioksidan terbesar terdapat pada buah tomat. Buah tomat dipercaya sebagai buah penghasil likopen yang terbaik serta mengandung vitamin A dan vitamin $C$ yang tinggi. Kandungan likopen di dalam buah tomat yakni $30-200$ $\mathrm{mg} / \mathrm{kg}$ buah segar (Myong dkk, 2013). Buah tomat selama proses pemasaran terutama di pasar-pasar tradisional dapat mengalami kerusakan hingga 40 \% (Wenli et al., 2001) . Buah tomat yang telah rusak selama pemasaran dapat dimanfaatkan sebagai sumber likopen.

Likopen termasuk dalam golongan karotenoid dengan nama lain alpha karoten yang memiliki pigmen merah terang. Senyawa likopen memiliki sifat antioksidan kuat yang mampu menangkal radikal bebas 100 kali lebih kuat dibanding tokoferol, sehingga sangat dibutuhkan oleh tubuh (Naziruddin, 2015).

Pemanfaatan likopen dalam minyak dapat mencegah oksidasi asam lemak tak jenuh dari minyak. Penelitian penggunaan buah tomat sebagai antioksidan telah dilakukan oleh Indriani (2018) dengan dicampurkan kedalam Virgin Coconut Oil (VCO) untuk mengetahui kadar likopen kasar buah tomat. Indriani et al. (2018) melaporkan bahwa likopen kasar buah tomat dalam VCO dengan rasio 5:40 (b/v) memiliki konsentrasi tertinggi pada penyimpanan mingggu pertama, yaitu 0,283 gram dan selanjutnya konsentrasi likopen akan terus menerus mengalami penurunan hingga minggu ketujuh sebesar 0,233 gram. Faktor yang mempengaruhi terjadinya kerusakan pada likopen, yaitu cahaya, suhu tinggi, oksigen, dan asam. Kerusakan tersebut terjadi melalui isomerasi dan oksidasi (Hamsina et al., 2019).

Pada penelitian ini, penggunaan likopen kasar buah tomat yang dicampurkan ke dalam minyak ikan lele dumbo dimaksudkan untuk mengetahui rasio terbaik likopen kasar dan masa penyimpanan minyak ikan lele dumbo. 


\section{METODE PENELITIAN}

\section{Bahan dan Peralatan}

Bahan yang digunakan pada meliputi buah tomat sayur atau tomat lokal yang telah matang dan ikan lele dumbo (Clarias gariepinus) (umur 3-4 bulan) yang diperoleh dari pasar Masomba Palu.

Alat yang digunakan adalah spektrofotometer UV-Vis PerkinElmer L850, mesin pres minyak ikan, neraca analitik, kuvet, corong pisah, ayakan 60 mesh, blender, dan oven.

\section{Prosedur Penelitian}

\section{Produksi likopen kasar buah tomat}

Buah tomat dibersihkan dan dipotong kecil-kecil, selanjutnya ditambahkan air dengan rasio 1:1 (b/v). Daging buah tomat dihancurkan dengan blender, selanjutnya dipanaskan pada suhu $70^{\circ} \mathrm{C}$ selama 30 menit. Ampas buah tomat dipisahkan dengan penyaringan dan dikeringkan dengan pengering surya hingga diperoleh crude likopen kering dengan berat yang kosntan. Likopen kasar dibuat menjadi serbuk dan diayak pada ukuran 60 mesh (Daniel et al., 2017).

\section{Ekstraksi minyak ikan lele}

Ekstraksi minyak ikan lele dilakukan dengan cara rendering basah. Ikan lele ditimbang $2 \mathrm{~kg}$ dan dikukus selama 2 jam, kemudian dipres. Cairan hasil press dimasukkan ke dalam corong pemisah dan dibiarkan hingga minyak terpisah dari air (Salasah et al., 2016).

\section{Pemurnian minyak ikan lele}

Sebanyak 50 gram arang aktif dipanaskan pada hot plate untuk mengaktifkan dan membuka pori-pori arang aktif. Selanjutnya diambil sebanyak 10 gram arang aktif yang telah dipanaskan kemudian ditambahkan 200
$\mathrm{mL}$ minyak ikan lele dan diaduk menggunakan magnetic stirrer selama 15 menit. Setelah pengadukan minyak disaring menggunakan kertas saring wathman nomor 42 (Evika, 2011).

\section{Perendaman likopen kasar buah tomat dalam minyak ikan lele dumbo}

Serbuk halus likopen kasar buah tomat dimasukan kedalam botol vial dan dicampur dengan minyak ikan lele dengan perbandingan 6:40, 8:40, 10:40 dan 12:40 (b/v), selanjutnya dikocok selama 10 menit dan disimpan selama 4 minggu pada suhu ruang. Setiap minggu dilakukan analisis kadar likopen dan bilangan perosida minyak.

\section{Analisis kadar likopen kasar buah tomat dalam minyak ikan lele}

Likopen ekstrak kasar buah tomat dalam minyak ikan lele yakni, campuran dikocok dan diamkan selama 4 minggu dengan taraf masing-masing pengamatan sesuai perlakuan (minggu 1, 2, 3, dan 4). Setiap minggu akan ditentukan kandungan bilangan peroksida dan panjang gelombang maksimum serta absorbansinya.

$$
C=\frac{A}{\varepsilon \cdot b}
$$

Keterangan

$C=$ Konsentrasi $(\mathrm{g} / \mathrm{mL})$

$A=$ Absorban

$\mathrm{b}=$ Tebal kuvet $(\mathrm{cm})$

$\varepsilon=$ Koefisien ekstingsi molar $(3450 \mathrm{ml} / \mathrm{g} \mathrm{cm})$

Analisis bilangan peroksida (AOAC, 1999)

Sampel minyak ikan lele sebanyak $5 \mathrm{~g}$ dimasukkan dalam labu Erlenmeyer dan ditambahkan $30 \mathrm{ml}$ larutan asam asetat dan kloroform dengan perbandingan 3:2, kemudian ditambahkan 0,5 $\mathrm{ml}$ larutan kalium iodida. Larutan campuran dikocok dan didiamkan 1 menit, kemudian ditambahkan $30 \mathrm{ml}$ aquades. Campuran ditambahkan $0,5 \mathrm{ml}$ indikator pati $1 \%$ sehingga berwarna biru tua, kemudian 
dititrasi dengan natrium tiosulfat $0,01 \mathrm{~N}$ hingga warna biru pudar atau hilang.

$$
\text { Nilai Peroksida }=\frac{\text { S. N. } 1000}{\text { Berat Sampel }}
$$

Keterangan :

$S=$ volume titrasi natrium tiosulfat $(\mathrm{mL})$,

$\mathrm{N}=$ Konsentrasi natrium tiosulfat $(0,01 \mathrm{~N})$

\section{HASIL DAN PEMBAHASAN}

\section{Ekstrak Likopen Kasar Buah Tomat}

Likopen kasar buah tomat yang diperoleh berwarna jingga-kemerahan dengan rendemen $2,42 \%$. Hal yang diperoleh relatif sama dengan hasil penelitian (Mappiratu et al., 2010) yang mengekstrak likopen dari buah tomat afkir, yakni $2,5 \%$.

Waktu perebusan dan suhu serta jenis dan tingkat kematangan buah tomat sangat berpengaruh terhadap kadar likopen buah tomat. Proses perebusan buah tomat berfungsi untuk membuka pori-pori daging buah tomat sehingga kandungan likopen dapat keluar lebih banyak akan tetapi semakin lama waktu perebusan buah tomat dapat membuat kandungan likopen menjadi rusak (Nugrohadi \& Limantara, 2008).

\section{Ekstrak Minyak Ikan Lele}

Minyak ikan lele yang diperoleh dari penelitian ini dengan cara pengukusan, pengepresan dan penyaringan menggunakan arang aktif memiliki warna minyak kuning dan rendemen minyak ikan lele yang dihasilkan 2.5\%, hasil ini berbeda dengan yang didapatkan oleh Eka et al. (2016) yakni rendemen minyak ikan lele 8,7\%. Hal ini dikarenakan penggunaan jenis ikan yang berbeda dan jumlah ikan yang digunakan lebih sedikit. Proses ekstraksi minyak ikan lele yang digunakan dalam penelitian ini adalah ekstrasi basah (wet rendering). Terdapat dua cara ekstraksi minyak ikan yaitu metode rendering basah (wet rendering) dan kering (dry rendering) (Eka et al., 2016).

\section{Kandungan Likopen Dan Minyak Ikan Lele Selama Penyimpanan}

Pengujian kualitas minyak ikan lele yang disimpan selama empat minggu, dilakukan untuk mengetahui pengaruh penambahan likopen kasar buah tomat selama masa penyimpanan. Pengujian minyak meliputi analisis kandungan likopen dan analisis bilangan peroksida pada minyak ikan lele.

Pengujian kadar likopen kasar buah tomat dalam minyak ikan lele diawali dengan tahap awal pengujian ekstrasi likopen kasar pada buah tomat. Kadar likopen kasar yang terkandung dalam buah tomat sebesar 0.701 gram. Menurut (Mappiratu et al., 2010) kadar likopen berpengaruh besar terhadap waktu perebusan buah tomat, suhu penyimpanan serta kandungan zat pelarut. Selanjutnya dilakukan pencampuran likopen kasar buah tomat dalam minyak ikan lele dengan masa penyimpanan selama empat minggu dan pengujian setiap minggu untuk mengetahui kandungan likopen dalam minyak.

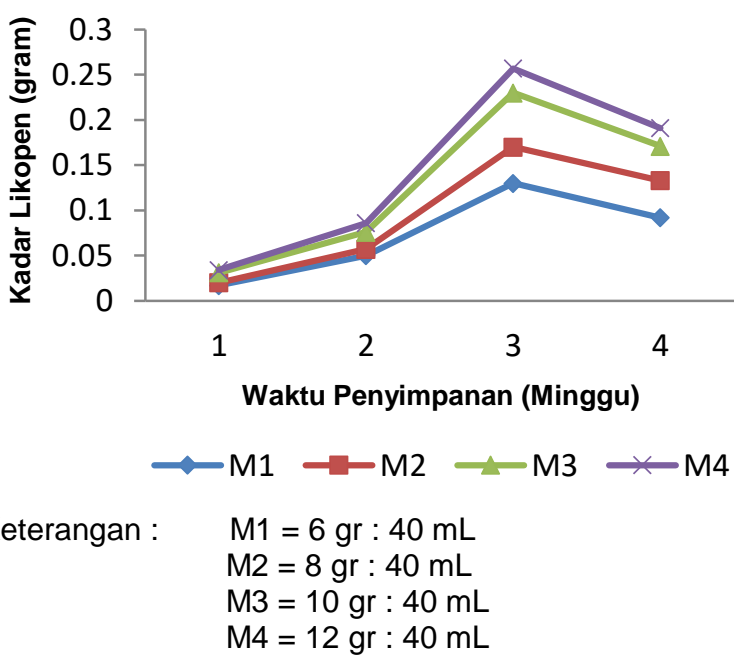

Gambar 1. Pengaruh waktu penyimpanan terhadap kadar likopen kasar dalam minyak ikan lele 
Dari grafik yang dipaparkan dapat dilihat bahwa rasio likopen kasar buah tomat: minyak ikan lele dumbo 12:40 (b/v) menghasilkan kandungan likopen yang sangat tinggi pada waktu penyimpanan minggu ke tiga, dibandingkan beberapa sampel dengan perbandingan rasio yang lebih rendah. Konsentrasi likopen dalam minyak ikan lele dari minggu pertama hingga minggu ke tiga terus mengalami kenaikan dengan kadar likopen tertinggi diperoleh 0,257 gram pada rasio 12:40. Hal ini diduga terjadi karena pada proses perendaman likopen kasar buah tomat ke dalam minyak ikan lele hingga minggu ketiga masih terjadi proses pelarutan likopen ke dalam minyak lelel sehingga senyawa likopen tersebut lebih mudah terdeteksi dalam minyak pada alat spektrofotometer Uv-Vis. Kadar likopen dalam minyak ikan lele dumbo mengalami penurunan setelah penyimpanan 4 minggu. Likopen setelah 4 minggu diasumsikan telah mengalami oksidasi sehingga terjadi kerusakan yang ditandai dengan memudarnya intensitas warna ekstrak likopen dalam minyak ikan lele dumbo. Senyawa likopen memiliki 11 ikatan rangkap terkonjugasi dalam strukturnya sehingga sangat mudah mengikat oksigen atau mudah teroksidasi (Dewi, 2018).

Penyimpanan juga dapat menyebabkan terjadinya perubahan bilangan peroksida pada minyak ikan lele dumbo. Bilangan peroksida mengalami peningkatanan pada semua perlakuan rasio likopen kasar buah tomat terhadap minyak ikan lele dumbo selama masa penyimpanan dari minggu pertama hingga minggu ke empat (Gambar 2). Akan tetapi, penghambatan terbentuknya peroksida dari proses oksidasi yang lebih tinggi terlihat pada perbandingan (M4) 12:40 (b/v) menunjukan terjadinya penghambatan kenaikan kadar bilangan peroksida dari minggu pertama sampai minggu ke tiga sebesar $3,45 \mathrm{meq} / \mathrm{Kg}$. Kemampuan penghambatan lebih baik jika dibandingkan dengan sampel minyak ikan pada sampel M1, M2, M3, dan kontrol (M) yang mengalami kenaikan kadar bilangan peroksida yang cukup tinggi pada minggu kedua sebesar $5,45 \mathrm{meq} / \mathrm{Kg}$, meq $/ \mathrm{Kg}, 3,83 \mathrm{meq} / \mathrm{Kg}$ dan 7,01 $\mathrm{meq} / \mathrm{Kg}$. Terlihat jelas bahwa minyak ikan lele tanpa likopen (M) sangat tidak tahan terhadap oksidasi sehingga bilangan peroksidanya tinggi. Likopen bersifat antioksidan pada minyak ikan lele yang menghambat radikal bebas membentuk senyawa peroksida.

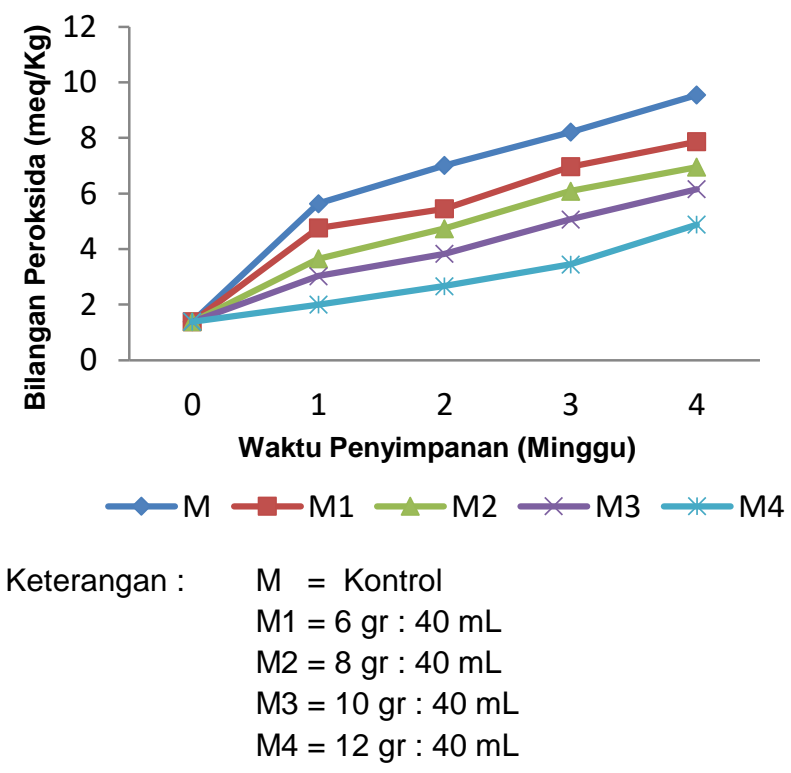

Gambar 2. Pengaruh penyimpanan terhadap kadar bilangan peroksida minyak ikan lele

Nilai oksidasi menjadi parameter mutu minyak yang sangat penting. Jika nilai oksidasi semakin rendah, maka mutu minyak juga semakin baik. International Fish Oil Standard (IFOS) menetapkan bahwa minyak dengan kategori layak konsumsi memiliki nilai bilangan peroksida $<3,75 \mathrm{meq} / \mathrm{Kg}$. Jika di bandingkan dengan hasil yang di dapatkan dengan standar mutu bilangan peroksida yang telah ditetapkan oleh IFOS maka untuk perbandingan M4 masih 
memenuhi standar layak konsumsi sampai minggu ke tiga, sedangkan sampel M1, M2, M3 hanya memenuhi standar kualitas bilangan peroksida sampai minggu ke dua dan untuk kontrol terus mengalami kenaikan yang cukup tinggi hingga $9.55 \mathrm{meq} / \mathrm{Kg}$ pada minggu ke empat. Menurut Indriani et al. (2018) pemberian perbandingan kosentrasi tertinggi likopen kasar buah tomat pada VCO menghasilkan kadar likopen tertinggi selama penyimpanan. Aidos et al. (2002) dalam Rozi, 2017) menjelaskan bahwa nilai peroksida sangat tergantung pada kemampuan otooksidasi dimana asam lemak tak jenuh dengan terbentuknya radikal-radikal bebas. Kerusakan minyak diawali oleh proses pembentukan radikal bebas pada asam lemak tak jenuh yang disebabkan oleh cahaya, panas, peroksida lemak, logam berat, dan enzim lipooksidase (Ketaren, 2008).

\section{KESIMPULAN}

Penggunaan 12 gram likopen kasar buah tomat dalam $40 \mathrm{ml}$ minyak ikan lele dumbo memiliki kadar likopen 0,257 selama penyimpanan tiga minggu. Penggunaan 12 gram likopen kasar dalam $40 \mathrm{ml}$ minyak ikan lele mampu menghambat terjadinya oksidasi minyak ikan lele dumbo dengan nilai bilangan peroksida terendah setelah minggu ketiga, yaitu $3,45 \mathrm{meq} / \mathrm{kg}$ atau memenuhi standar IFOS.

\section{DAFTAR PUSTAKA}

AOAC. (1999). Official Methods of Analysis of the Association of Official Analytical ChemistInternational, 16th ed. AOAC Inc.

Burhan, A. handayani. (2018). Penetapan Angka Peroksida Minyak Goreng Curah Sawit Pada Penggorengan Berulang Ikan Lele. JURNAL PENDIDIKAN SAINS (JPS), $\quad$ 6(2): $\quad$ 48-53. https://doi.org/10.26714/jps.6.2.2018.4853

Daniel, K., Mappiratu, M., \& Sumarni, N. K. (2017). Penentuan Masa Kadaluarsa Likopen Dari Buah Tomat (Lycopersicum pyriforme) Tercampur Maltodekstrin Dalam Kemasan Kapsul. KOVALEN: Jurnal Riset Kimia, 3(3): 223-233.

Dewi, E. S. (2018). Isolasi Likopen Dari Buah Tomat (Lycopersicum esculentum) Dengan Pelarut Heksana. Jurnal Agrotek Ummat, $\quad$ 5(2): 123-126. https://doi.org/10.31764/agrotek.v5i2.70 7

Eka, B., Junianto, \& Rochima, E. (2016). Pengaruh Metode Rendering Terhadap Karakteristik Fisik, Kimia Dan Organoleptik Ekstrak Kasar Minyak Ikan Lele. Jurnal Perikanan Kelautan, 7(1): 15.

Erdman, J., Jhon, W., Macdonald, I., \& Zeisel, S. (2012). Present Knowledge in Nutrition Tenth Edition. International Life Sciences Institute.

Evika. (2011). Penggunaan Adsorben Arang Aktif Tempurung Kelapa Pada Pemurnian Minyak Goreng Bekas [Skripsi]. Universitas Islam Negeri Sultan Syarif Kasim.

Hamsina, Hasani, R., \& Irfan. (2019). Optimasi Proses Ekstraksi Senyawa Likopen Dari Buah Semangka Dengan Menggunakan Variasi Pelarut. Prosiding Seminar Nasional Penelitian \& Pengabdian Kepada Masyarakat (SNP2M), 59-63.

Indriani, E., Ruslan, R., Prismawiryanti, P., \& Satrimafitrah, P. (2018). Kadar Likopen Ekstrak Kasar Buah Tomat Dalam Vco (Virgin Coconut Oil) Pada Perendaman Suhu Ruang. KOVALEN: Jurnal Riset Kimia, 4(2): 174-179.

Ketaren, S. (2008). Pengantar teknologi minyak dan lemak pangan. UI Press, Depok.

Mappiratu, Nurhaeni, \& Israwati, I. (2010). Pemanfaatan tomat afkiran untuk produksi likopen. Media Litbang Sulteng, 3(1): 64-69. 
Naziruddin, A. (2015). Pengaruh Penambahan Minyak Nabati Terhadap Kandungan Senyawa Likopen Pada Tomat (Lycopersicum esculentum Mill) [Skripsi]. Universitas Hasanuddin, Makassar.

Ngadiarti, I., Kusharto, C. M., Briawan, D., \& Marliyati, S. A. (2013). Kandungan Asam Lemak dan Karakteristik Fisiko-Kimia Minyak Ikan Lele dan Minyak Ikan Lele Terfermentasi. Penelitian Gizi dan Makanan, 36(1): 82-90.

Nugrohadi, S., \& Limantara, L. (2008). Likopen: Antioksidan Alifatik yang Efektif. Prosiding Seminar Nasional Pigmen, 2008, 367-377.

Rozi, A. (2017). Karakterisasi Hasil Pemurnian Minyak Hati Ikan Cucut Pisang (Charcharinus falciformis). JURNAL PERIKANAN TROPIS, 4(2): 114-125. https://doi.org/10.35308/jpt.v4i2.785

Salasah, R., Mappiratu, M., \& Nilawati, J. (2016). Kajian Peningkatan Asam Lemak Omega-3 EPA dan DHA Pada Minyak Ikan Lele Yang Diberi Pakan Minyak Kacang Kedelai. Mitra Sains, 4(2): 1-12.

Suyanto, S. (2006). Budidaya Ikan Lele. Penebar Swadaya, Jakarta.

Wenli, Y., Yaping, Z., Zhen, X., Hui, J., \& Dapu, W. (2001). The antioxidant properties of lycopene concentrate extracted from tomato paste. Journal of the American Oil Chemists' Society, 78(7): 697-701. https://doi.org/10.1007/s11746-0010328-6 